\section{We have got to up our game substantially for forests, carbon, biodiversity, and ultimately people}

A recently published contribution in Nature by Lenton et al. (2019) shows that Earth is risking an irreversible planetary tipping point. This means that the Earth's climate system is in a state of emergency, rushing its way towards a point of no return. The authors have identified nine tipping points-inter alia-melting Arctic and Antarctic ice sheets, retreating permafrost, changing boreal forest fire and pest regimes, and increased frequency of droughts in the Amazon forest. These signals are raising global concerns. While science expected these tipping points to be reached at $3^{\circ} \mathrm{C}$ increase (e.g., Lemoine and Traeger 2016), recent trends are corroborating the hypothesis that these points of irreversible and abrupt system change already show high probability of being reached within the bounds of $1.5-2^{\circ} \mathrm{C}$. During the COP21 of the United Nation Framework Convention on Climate Change (UNFCCC), 195 countries adopted the Paris Agreement to limit global temperature rise to well below $2^{\circ} \mathrm{C}$.

Planetary boundaries are shifting and we are facing a global environmental crisis. What does this mean for forests and biodiversity? A report released in May this year by the Intergovernmental Science-Policy Platform on Biodiversity and Ecosystem Services (IPBES) - the Intergovernmental Panel on Climate Change (IPCC)-pendant for biodiversity - shows that 1 million animal and plant species are at high risk of extinction due to deforestation, overfishing, and other human activities (Tollefson 2019). Forests-tropical, temperate, and boreal-are home to the majority of all terrestrial species. Deforestation continues unabated and thus the risk of losing biodiversity increases. Deforestation is taking place mainly in the tropics, also because the largest forest areas are pantropical. Fifteen percent of tropical forests are designated for the conservation of biodiversity versus $13 \%$ at the global level (Pancel and Köhl 2016). The Global Deal for Nature (GDN) - a science-driven plan to save the diversity and abundance of life on our planet-suggests to increase conservation efforts: by 2030 we need $30 \%$ of the terrestrial area under protection for biodiversity conservation, with an additional $20 \%$ for climate buffering in order to stay below the $1.5^{\circ} \mathrm{C}$ threshold (Dinerstein et al. 2019). Reasons for deforestation are the usual suspects but vary from region to region. In Latin America and South East Asia, commodity driven deforestation accounts for 64 and $61 \%$, respectively. In Africa, 93\% is due to subsistence agriculture. At higher latitudes, deforestation is mainly an affair between wildfires (59\%
Russia/ China/ South Asia) and forestry production (95\% in Europe, $48 \%$ in North America); $68 \%$ of Australia's deforestation is caused by wildfires (Curtis et al. 2018).

Burning forests have been in global media for a large portion of the past months, especially tropical forests with high biodiversity. Interestingly, when temperate forests in rich countries burn, media report on property loss, desperate people and economic aspects but seldom on loss in biodiversity or climate change. The Amazon made headlines due to ever-increasing fires, despite this year not having been exceptionally dry (Barlow et al. 2019). Should deforestation continue, a tipping point will be reached far sooner than expected (Lovejoy and Nobre 2018). Other global fire hotspots-with less media attention-burning every year (here we are not referring to wildfires but human induced fires) are Congo Basin, Indonesia, and Malaysia (Gaveau et al. 2018, Turubanova et al. 2018, Tyukavina et al. 2018). These regions are renowned for high biodiversity but also for highly contested land used for production, be it small-scale subsistence farming or commodity production at larger scales.

Humans are driving a lot of (land-use based) change, while the climate is acting as the Uber-driver and amplifier, potentially reducing system resilience and pushing trends beyond breaking points. Is Earth lost, or is there a shred of hope left? Well, we would be more than happy to report here that things are actually on a good track. There certainly is a global awareness across regions, countries, and societies that we humans need to take care of our planet. At the UN level, a number of initiatives embarked to restore and reforest our planet to turn the tide within this decade with a growing number of countries, corporations, civil societies, indigenous people and NGOs endorsing reforestation. Many pledges have been making global headlines. However, a recently published five years assessment by the New York Declaration on Forests shows a rather sombre picture. Since the declaration's inauguration in 2014, more than 200 parties have endorsed the stated targets and goals. Yet, compared to the 2002-2013 baseline, tropical primary forest loss has accelerated by $44 \%$ (4.3 million hectares per year versus $3 \mathrm{M}$ hectares per year baseline). The stated targets for 2020 will be impossible to meet (NYDF Assessment Partners 2019). Have we failed? Almost.

A study assessing the numbers of trees on Earth published by Crowther et al. (2015) made the restoration initiatives change gears and relabel their campaign from the billion trees to the trillion trees campaign. Since, reforestation has dramatically gained in momentum. However, trying to get numbers on how many forest restoration landscape (FLR) projects have been undertaken in the past five years has proven to be difficult since there are many different initiatives at various scales involving various groups of actors, making the task of keeping track challenging. Lewis et al. (2019) calculated that based on the 43 Bonn Challenge countries, and based on their pledges/goal to reforest $350 \mathrm{M}$ hectares by 2030, outcomes of carbon sequestration depend on the forest strategy applied. Forty-two pentagrams of carbon (PgC) could be stored by the year 2100 if the entirety of pledges would actually reach the $350 \mathrm{M}$ hectares and be fully based on natural regeneration. If the strategy would be for agroforestry, 7 PgC would be sequestered, and under monoculture only 1PgC. By 2019, a total of 


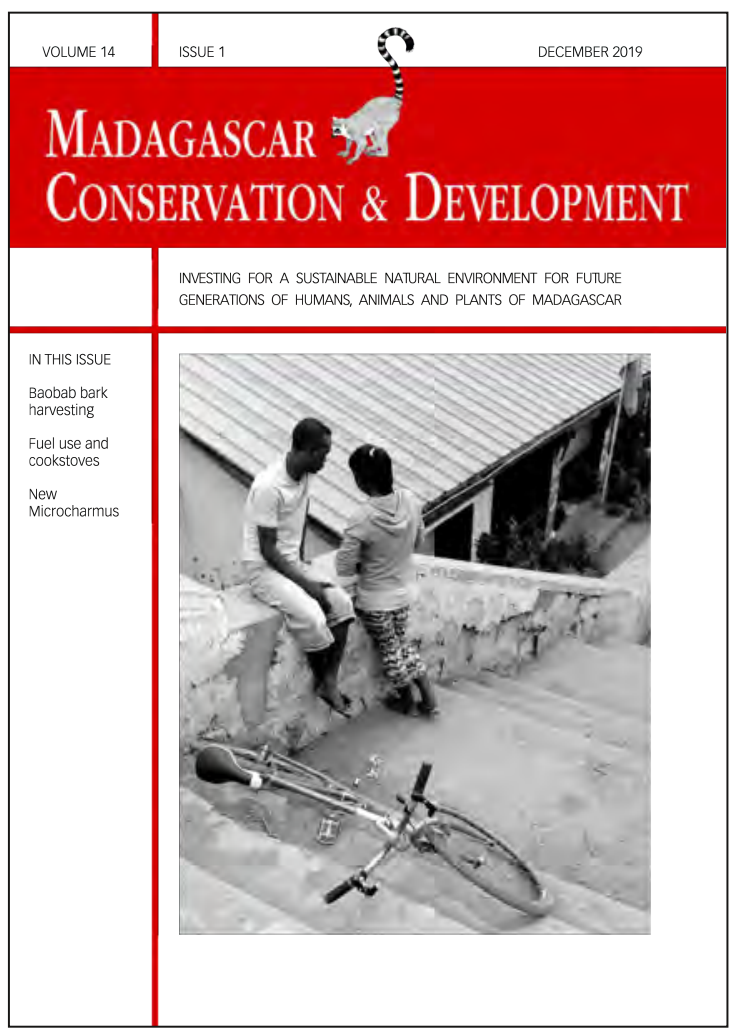

Madagascar Conservation \& Development is the journal of Indian Ocean e-Ink. It is produced under the responsibility of this institution. The views expressed in contributions to MCD are solely those of the authors and not those of the journal editors or the publisher.

All the Issues and articles are freely available at http://www.journalmcd.com

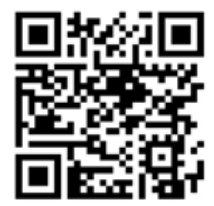

Contact Journal MCD

info@journalmcd.net for general inquiries regarding MCD funding@journalmcd.net to support the journal

Madagascar Conservation \& Development Institute and Museum of Anthropology

University of Zurich

Winterthurerstrasse 190

$\mathrm{CH}-8057$ Zurich

Switzerland

Indian Ocean e-Ink

Promoting African Publishing and Education

www.ioeink.com

Missouri Botanical Garden (MBG)

Madagascar Research and Conservation Program

Missouri Botanical Garden BP 3391

Antananarivo, 101, Madagascar 
292M hectares had been pledged for restoration. Out of these, only $34 \%$ of area for restoration are to fall under the natural regeneration strategy (with the lowest implementation cost), 21\% account for agroforestry, while $45 \%$ of all commitments involve the planting of monocultures. According to the IPCC, $199 \mathrm{PgC}$ need to be removed from the atmosphere by 2100 to keep global warming below the $1.5^{\circ} \mathrm{C}$. Of course, reforestation is just one pathway to achieve this. However, the right restoration strategy needs to be envisaged, while also keeping an eye on deforestation. "Restoring forests can't offset forest loss. They have to be complementary, and they have to be done at the same time" (Stephanie Roe, one of the NYDF assessment lead author in an interview for Mongabay 2019).

Madagascar's forests host some $80 \%$ of its terrestrial biodiversity (Waeber et al. 2019) and is threatened by ongoing deforestation. Madagascar - a signatory to the Bonn Challenge and now also member of the African Forest Landscape Restoration Initiative AFR100-has pledged to restore 4M hectares by 2030. In this context, the president of Madagascar announced in 2019 a plan to annually plant trees on 40,000 hectares over five years. These are ambitious plans. Madagascar's FLR strategy, released in early 2017, identifies main governance challenges and the need for trans-sectoral collaboration. A study conducted by CIFOR (Ranjatson et al. 2019) identified main barriers to implementation in the lack of weak forest law enforcement and particularly tenure security for smallholder farmers, an issue still unresolved despite years of REDD+ experience in Madagascar (Hockley et al. 2018). Unresolved land tenures are a recipe for trouble. In a frenzy to achieve the set targets, mainly fast growing exotic species such as pine, acacia and eucalyptus risk to be favoured to serve harvesting for firewood, charcoal or construction. The 22 regions in Madagascar are each responsible to reforest some 2000 hectares. The regional governments, on their turn, rely on schools, NGOs, or the private sector to fulfil the goal. However, there are no guidelines provided by the government on how and where to target land with what kind of native species. The government also plans to use drones to spread seeds in remote areas. However, even after 30 years of natural restoration, a recovering forest is much poorer in terms of species richness, abundance and composition (Klanderud et al. 2010).

According to Lenton et al. 2019, in order to reduce the chances of these irreversible changes actually happening, countries need to ensure that greenhouse gas emissions do not lead to an increase above $1.5^{\circ} \mathrm{C}$. It would take, however, at least 30 years to achieve this target-time we do not have anymore. Governments seem not to have the power nor maybe the necessary long-term vision to step up to the plate, while other segments of society have shown more courage. It seems quite embarrassing that young people like Greta Thurnberg have to skip school in order to protest for our Earth-we have the highest admiration for such civil courage and perseverance. Many scientists and conservationists should mustard up some of hers, speak out, and take action on their own warnings to humanity (Gardner and Wordley 2019). There will be more and more such protests in the future, where societies are tired of the political inertia and corporate greediness, irresponsibility and non-accountability (many of these are directly or indirectly driving deforestation for the production of commodities). We need transformational partnerships where politics, representatives from the corporate and financial worlds, NGOs and civil societies sit at one table and start talking about tangible and feasible actions. Scientists and practitioners need to provide and share expert guidance when it comes to restoration and reforestation. We need locally tailored solutions; there is not one-fits-all solution. Verbatim intentions alone will not suffice to slow down negative trends or even reverse them. Wrong planning and planting risks only to exacerbate and undermine good intentions. The right trees need to be put in the right place and need to benefit the people in the vicinity. A robust and systematic monitoring needs to accompany the process of restoration while reporting needs to adhere to ethical principles of transparency, accountability and timeliness. Time for voluntary, non-binding commitments is over.

\section{Patrick O. Waeber}

Forest Management and Development

Swiss Federal Institute of Technology (ETH) Zurich, switzerland powaeber@gmail.com; patrick.waeber@usys.ethz.ch

\section{Lucienne Wilmé}

Missouri Botanical Garden

Madagascar Research \& Conservation Program, BP 3391, Antananarivo 101

lucienne.wilme@mobot-mg.org

\section{REFERENCES}

Barlow, J., Berenguer, E., Carmenta, R. and França, F. 2019. Clarifying Amazonia's burning crisis. Global change biology. <https://doi.org/10.1111/gcb.14872>

Crowther, T. W., Glick, H. B., Covey, K. R., Bettigole, C., Maynard, D. S., et al. 2015. Mapping tree density at a global scale. Nature 525: 201-205. <https://doi.org/10.1038/nature14967>

Curtis, P. G., Slay, C. M., Harris, N. L., Tyukavina, A., \& Hansen, M. C. 2018. Classifying drivers of global forest loss. Science 361, 6407: 1108-1111. <https://doi.org/10.1126/science.aau3445>

Dinerstein, E., Vynne, C., Sala, E., Joshi, A. R., Fernando, S., et al. 2019. A global deal for nature: guiding principles, milestones, and targets. Science Advances 5, 4: eaaw2869. <https://doi.org/10.1126/sciadv.aaw2869>

Gardner, C. J. and Wordley, C. F. 2019. Scientists must act on our own warnings to humanity. Nature Ecology \& Evolution 3, 9: 1271-1272. $<$ https://doi.org/10.1038/s41559-019-0979-y>

Gaveau, D. L., Locatelli, B., Salim, M. A., Yaen, H., Pacheco, P. and Sheil, D. 2018. Rise and fall of forest loss and industrial plantations in Borneo (2000-2017). Conservation Letters 12, 3: e12622. <https://doi.org/10.1111/conl.12622>

Hockley, N., Mandimbiniaina, R. and Rakotonarivo, O. S. 2018. Fair and equitable conservation: do we really want it, and if so, do we know how to achieve it? Madagascar Conservation \& Development 13, 1: 3-5. $<$ https://doi.org/10.4314/mcd.v13i1.11>

Lemoine, D. and Traeger, C. P. 2016. Economics of tipping the climate dominoes, Nature Climate Change 6, 5: 514-519. <https://doi.org/10.1038/nclimate2902>

Lenton, T. M., Rockström, J., Gaffney, O., Rahmstorf, S., Richardson, K., et al. 2019. Climate tipping points—-too risky to bet against. Nature 575: 592-595. <https://doi.org/10.1038/d41586-019-03595-0>

Lovejoy, T. E. and Nobre, C. 2018. Amazon tipping point. Science Advances 4, 2 eaat2340. <https://doi.org/10.1126/sciadv.aat2340>

Mongabay. 2019. Worldwide deforestation rising despite bold commitments, report finds. Available online <https://news.mongabay.com/2019/09/worldwide-deforestation-rising-despite-bold-commitments-report-finds/> 
NYDF Assessment Partners. 2019. Protecting and Restoring Forests: A Story of Large Commitments yet Limited Progress. New York Declaration on Forests Five-Year Assessment Report. Climate Focus (coordinator and editor). Available online <https://forestdeclaration.org>

Pancel, L. and Köhl, M. 2016. Tropical Forestry Handbook. Springer Berlin Heidelberg 4 vol.: i-|X,1-3633. <https://doi.org/10.1007/978-3-642-41554-8>

Ranjatson, P., McLain, R., Mananga, J., Randrianasolo, R., Razafimbelo, Ny T., Lawry, S. 2019. Tenure Security and Forest Landscape Restoration: Results from Exploratory Results from Explanatory Research in Boeny, Madagascar. Paper prepared for presentation at the" 2019 World Bank Conference On Land And Poverty". The World Bank, Washington DC. Available online <http://www.cifor.org/publications/pdf_files/Papers/PMcLain1901.pdfs

Styger, E., Rakotondramasy, H. M., Pfeffer, M. J., Fernandes, E. C. andBates, D. M. 2007. Influence of slash-and-burn farming practices on fallow succession and land degradation in the rainforest region of Madagascar. Agriculture Ecosystems \& Environment 119(3-4): 257-269. <https://doi.org/10.1016/j.agee.2006.07.012>

Tollefson, J. 2019. Humans are driving one million species to extinction. Nature 569: 171. <https://doi.org/10.1038/d41586-019-01448-4>

Turubanova, S., Potapov, P. V., Tyukavina, A. and Hansen, M. C. 2018. Ongoing primary forest loss in Brazil, Democratic Republic of the Congo, and Indonesia. Environmental Research Letters 13, 7: 074028. <https://doi.org/10.1088/1748-9326/aacd1C>

Tyukavina, A., Hansen, M. C., Potapov, P., Parker, D., Okpa, C., Stehman, S. V., et al 2018. Congo Basin forest loss dominated by increasing smallholder clearing. Science Advances 4, 11: eaat2993. $<$ https://doi.org/10.1126/sciadv.aat2993>

Waeber, P. O., Rafanoharana, S., Rasamuel, H. A. and Wilmé, L. 2019. Parks and reserves in Madagascar: managing biodiversity for a sustainable future. [Online First], Intechopen. <https://doi.org/10.5772/intechopen.85348> 